\title{
MICROCLIMATE AND MICROBIAL CHARACTERIZATION IN THE ZINZULUSA SHOW CAVE (SOUTH ITALY) AFTER SWITCHING TO LED LIGHTING
}

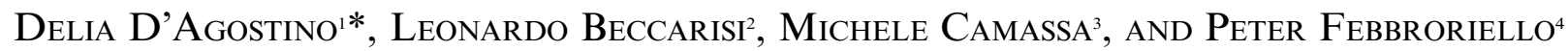

\begin{abstract}
Show caves are vulnerable environments whose conditions should be monitored over time. Many factors, such as visits by tourists and the installation of lights, can easily alter the equilibrium of the cave system. Grotta Zinzulusa is a show cave located on the southeastern coast of Italy. This cave is renowned for the richness of its faunal biodiversity, but little is known about its microclimate and about its microbial diversity in the form of lampenflora growth near the light sources. We investigated the photosynthetic microorganisms living in the Zinzulusa in regard to its microclimatic conditions one year after the change of the lighting system from tungsten to LED (light emitting diode) lamps. Most microbial activity was found in areas with vermiculations. We established four distinct communities based on macroscopic characteristics as a function of light intensity and wavelength. The observations were compared both with previous data collected in the last decade and with other caves reported in the literature. Results show that not much has changed within the first year after switching to a LED system with respect to the 1999 state. This research contributes to the knowledge of the environmental attributes and provides a baseline to check for changes in the lampenflora community over time in the Zinzulusa.
\end{abstract}

\section{INTRODUCTION}

Show caves provide important financial and educational opportunities for the increase in nature-based tourism (Hamilton-Smith, 2004). Opening caves to the public brings changes that alter the environment, such as construction of walking surfaces and infrastructure for electricity and water (Mulec, 2014). Recreational use of caves dates back to the early seventeenth century (Šebela and Turk, 2014). Nowadays, more than six hundred show caves are operating worldwide (Gillieson, 2011). The number of tourists visiting caves is continually increasing and can reach half a million visits per year in caves such as Grotte di Castellana in Italy and Han sur Lesse in Belgium (Parise, 2011).

The presence of large numbers of tourists can alter the natural microclimatic and environmental conditions of a cave, with consequences for the equilibrium of the system (Cigna, 2004). In particular, temperature and humidity can increase considerably within the cave due to the presence of tourists (Russell and MacLean, 2008). Moreover, human respiration can lead to an augmented $\mathrm{CO}_{2}$ concentration that can promote speleothem corrosion (Baker and Genty, 1998). Visitors often contribute to the introduction of microorganisms and foreign species into caves (Gamble et al., 2000). The presence of these microorganisms creates management complications in many caves. Tourists also contribute to lint accumulation that supports the growth of bacteria on natural fibres, leading to discoloration or damage to speleothems. Other factors, such as the introduction of mud and dust, may adversely impact the equilibrium of hypogean caves.
In the artificially illuminated parts of caves, the development of heterotrophic biofilms (Jurado et al., 2009; Saiz-Jimenez et al., 2011) and phototrophic communities serving as primary producers (Bastian and Alabouvette, 2009) is common. This community, generally known as lampenflora, is usually composed of different microbes, eukaryote algae, cyanobacteria, bryophytes, mosses, and ferns. It adheres strongly to the substratum and deteriorates speleothems and other objects (Mulec, 2012). Nutrients and moisture levels are often sufficient to support its growth (Mulec et al., 2008). Rock surfaces, sediments, and artificial materials around lamps often become colonized by these phototrophs (Dobat, 1998a). Biomass fixed due to light energy, together with other organic matter brought by tourists on clothing and skin, becomes available to cave organisms. Light sources can contribute to a temperature increase that further supports their proliferation. The lighting system can alter the microclimate, favoring the growth of photosynthetic organisms, as happened in the Lascaux caves, France, where algal colonization damaged the cave paintings (Baker and Genty, 1998). Lampenflora is completely dependent on light, as the light saturation point of these species is quickly reached at the

\footnotetext{
*Correspondence author: delia.dagostino@unisalento.it

${ }^{1}$ Department of Material Science - University of Salento, 73047, Monteroni di Lecce (Lecce), Italy

${ }^{2}$ Regional Natural Park "Costa Otranto-Santa Maria di Leuca e Bosco di Tricase", Andrano (Lecce), Italy

${ }^{3}$ Istituto Sperimentale of "Biologia del Sottosuolo P. Parenzan", 72022, Latiano (Brindisi), Italy

${ }^{4}$ Research Support Group, Torrington CT, USA
}

Journal of Cave and Karst Studies, December 2015 • 133 
cave temperature (Dobat, 1998b). Moreover, some cyanobacteria and micro-algae can survive even at photon flux densities lower than their photosynthetic compensation point (Mulec and Kosi, 2009).

These phototrophic communities are inappropriate from an aesthetic point of view and cause degradation of colonized substrata, producing weak organic acids that can slowly corrode the speleothems. Until now, the most common treatments for controlling lampenflora growth included physical abrasion and bleach solutions. Hydrogen peroxide seems to be the most favorable biocidal among the tested chemicals (Faimon et al. 2003; Mulec and Kosi 2009). These methods can be replaced with a proper selection of time-limited illumination, reduction of light intensity and the use of lights whose spectrum does not support photosynthesis, such as light-emitting-diode (LED) systems (Olson, 2006 and references therein). In the Frozen Niagara section of the Mammoth cave, Olson (2006) monitored a narrow spectrum yellow LED $(595 \mathrm{~nm})$ with an intensity of 49.5 lux, corresponding to double the value recommended for white light by Aley (2004). After one year, a reduction of lampenflora growth was observed where previously a widespread algal cover was present (Toomey et al., 2009).

Some cave managers ignore light and tourist pollution until problems become very obvious and difficult to solve. Therefore, due to the high vulnerability of these environments, it is important to know their specific physical and biological attributes and constantly monitor their conditions. Remediation actions that are done without careful planning may not solve, or may even exacerbate, the problem. The installation of a new lighting system should be preceded by specific surveys. To minimize visitor impact, cave managers need to ensure a sustainable development of the cave system (Gillieson, 1996). Hence the introduction of a climatic and biological monitoring program should assist those involved in the adviser role to define and maintain a suitable environmental status in these systems (de Freitas and Littlejohn, 1987).

\section{Materials AND Methods}

Grotta Zinzulusa (Fig. 1a) is a karst cave facing the Adriatic Sea in the southeastern coast of Italy near the town of Castro, in the province of Lecce. Monitoring in Zinzulusa was aimed at investigating the microbial diversity established in the cave compared to its microclimatic conditions. With this aim, the following types of surveys were performed: microclimatic surveys to describe temperature and humidity inside the cave; analysis of the algal and microbiological communities checking their macroscopic characteristics; surveys to analyze the distribution of phototrophic organisms in response to light intensity; and microbiological surveys to investigate the composition of vermicular formations, as well as identifying bacteria and fungi. The research was carried out in the air-filled part of the cave (Fig. 2a) between March 2008 and December 2009. Additional data were used to evaluate the response of the cave environment to the new LED system that replaced tungsten incandescent lamps, among them microclimatic data available from December 2007 to March 2008 and microbiological data from 1999.

\section{GrotTa ZinZulusA}

Grotta Zinzulusa is a renowned show cave located on the southeastern coast of Italy (Fig. 1a). It develops in a westerly direction for $156.5 \mathrm{~m}$, at $11 \mathrm{~m}$ above sea level. The cave has a large entrance opening onto the Adriatic Sea (Fig. 1b) and is the result of a long karst erosive process during the Pleistocene. The cave was discovered in 1793, and it has been accessible to tourists since 1975. Grotta Zinzulusa is visited by about 130,000 people annually, and many facilities were built for tourists, including a passage excavated into the cliff to allow entrance into the cave (Ciccarese and Pesce, 1999). An internal walkway and a lighting system were installed between 1950 and 1957 to permit an easy visit in most of the air-filled part of the cave.

The cave can be divided into two parts, air-filled (Fig. 2a) and submerged (Onorato et al., 1999). The higher part can be itself divided into three parts. The first, from the entrance to the Crypt, is characterized by numerous speleothems (Fig. 1d) and a brackish pool, the Basin, that contains marine species (Toomey et al., 2009). The second area, from the Crypt to the Cathedral, contains fewer stalactites and stalagmites. In the final part, there is a $1.5 \mathrm{~m}$ deep freshwater pool, the Cocito, of cold brackish water in an area closed to visitors. The pool's water level often fluctuates with tidal changes due to the coastal location and the connection with the sea. This pool confirms the anchialine nature of the hydrological system. In this location, the rich diversity of fauna includes crustaceans, copepods, and blind fishes. The Cocito is a sump where the submerged part of the cave starts, and has been explored for about $120 \mathrm{~m}$ and is composed of many rooms connected by short passages. Unlike the entrance, which was subjected to marine erosive processes, the other parts were formed through a long karst process of carbonate rock dissolution (Parenzan, 1963).

More than sixty terrestrial and aquatic species have been identified in Zinzulusa. Among them are bats and anchialine species of ancient origin (Pesce, 2001). However, as in other caves (Fong, 2011), changes in the environment caused some animals, such as bats, to abandon their natural habitat. In 1999 the Karst Waters Institute included Grotta Zinzulusa in the top-ten list of the world endangered karst ecosystems (Belson, 1999). This was mainly due to tourist impact on natural formations, as well as pollution from urban water discharges that threatens the hypogean environment. Grotta Zinzulusa presents an abundance of vermicular clay-slime formations (Camassa and Febbroriello, 2003) whose origin is still unknown, spreading on the cave surfaces and the calcite speleothems (Fig. 2b). Various theories have been published about the origin of vermiculations 

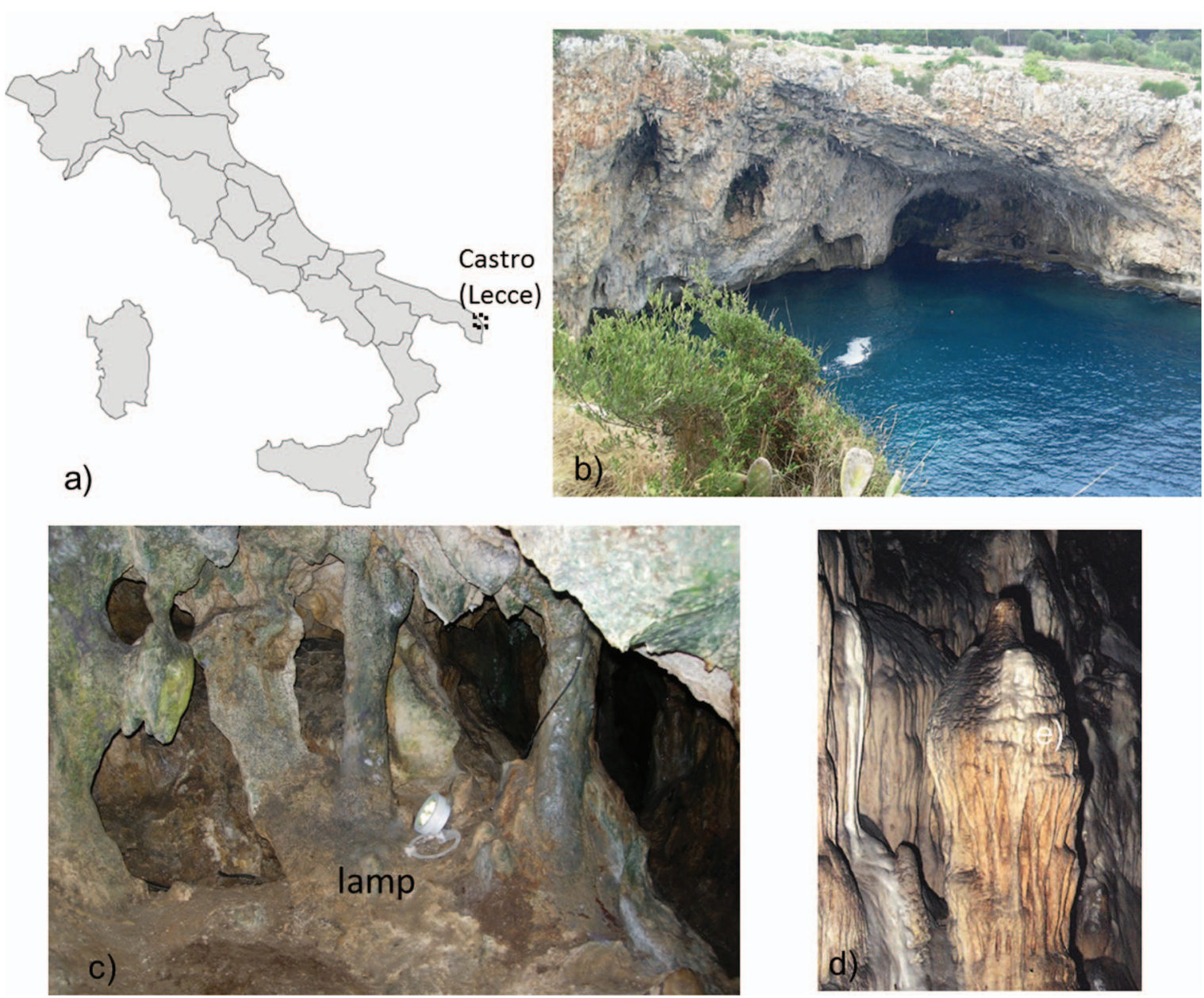

Figure 1. Grotta Zinzulusa, southeastern Italy: a) location. b) Natural entrance. c) Inside near the Crypt (Fig. 2a); a lamp is visible in the picture. d) Speleothems.

and the development of those formations on cave walls and speleothems (Nováková, 2009). Due to their biotic component, they represent a food source for microorganisms. Furthermore, the production of metabolic acids, especially lactic and succinic, is involved in the surface bioerosion of speleothems (Northup and Lavoie, 2001; Camassa, 2003) or litholitic processes (Mulec et al., 2007)

Lampenflora growth has been visible for a long time near the lights in Zinzulusa (Fig. 1c). To remove it, repeated applications of bleach were applied in the past, without investigating the relationship between microorganisms and lights. Grotta Zinzulusa has been examined for its faunal biodiversity (Pesce, 2001), but in the international literature there are no specific studies on its lampenflora and microbiological characteristics.

A LED system was installed in March 2008, consisting of spotlights with six to nine 1 watt LEDs without UV and IR spectral components. This system replaced tungsten incandescent lamps that emitted from $100 \mathrm{~W}$ to $200 \mathrm{~W}$, increasing temperature and decreasing relative humidity. The new system was selected for various reasons: to have a lower impact on the microclimate, to reduce the lampenflora, to darken selected areas to benefit species having conservation issues, such as bats that were abundant between the Cathedral and Cocito (Lazzari, 1966), and to enhance the visibility for visitors inside the cave. Each diode furnishes a white light of maximum intensity of 45 lux, with narrow peaks in red $(620-630 \mathrm{~nm})$, green $(515-530 \mathrm{~nm})$ and yellow-amber $(585-595 \mathrm{~nm})$ wavelengths and minimal amounts of UV. This range of wavelengths is unfavorable for chlorophyll photosynthesis (Teramura and Sullivan, 1984). The lighting system is turned on during the visiting hours of the cave, which last for eight hours daily in summer and six hours during the other seasons.

\section{The Microclimate}

In connection with the installation of the new lighting system, microclimatic monitoring was performed by the University of Salento, commissioned by the Castro municipality that provided permission to publish all the data. Data were automatically recorded every 15 minutes using ten data loggers (numbered 1-10 in Fig. 2a) provided with

Journal of Cave and Karst Studies, December 2015 • 135 


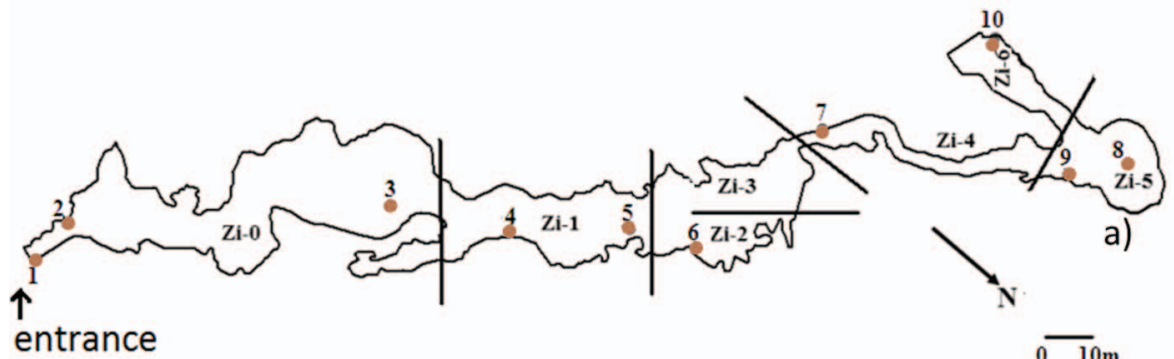

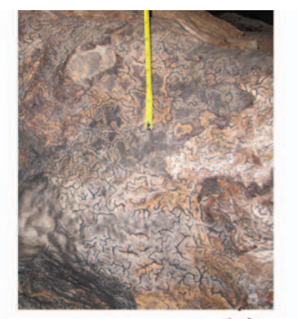

b)

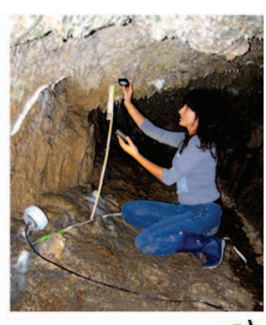

c)

Figure 2. a) Plan map of the air-filled part of Grotta Zinzulusa, modified from Onorato et al. (1999), showing the points of the microclimatic survey performed by the University of Salento commissioned by the Castro municipality (1. Entrance Chamber, 2. Vestibule, 3. Pond, 4. Trap, 5. Canopy, 6. Waterfall, 7. Crypt, 8. Cathedral 1, 9. Cathedral 2, 10. Cocito), and the sampling areas for the microbiological surveys ( $\mathrm{Zi}-0$ through $\mathrm{Zi}-6)$ divided by lines. b) Vermicular formations in the cave. c) Collecting light intensity data.

sensors for temperature (range from -25 to $+85^{\circ} \mathrm{C}$, accuracy $\pm 0.5{ }^{\circ} \mathrm{C}$, resolution $0.01{ }^{\circ} \mathrm{C}$ ) and relative humidity (range from 0 to $100 \%$, accuracy $\pm 2 \%$, resolution $0.5 \%$ ). One data logger was placed outdoors to analyze the impact of the outside climate on the cave interior. The others were placed inside the cave, from the entrance (point 1 in Fig. 2a) up to the Cocito pool (point 10). These locations were selected to cover the air-filled part of the cave to analyze the microclimatic changes related to the increased use of the cave for tourism. The names of these locations originate from features in the cave. Starting from the entrance (Fig. 2a), the identified locations included: the Vestibule (point 2), the Pond (point 3), the Trap (point 4), the Canopy (point 5), the Waterfall (point 6), the Crypt (point 7), and the Cathedral (points 8 and 9).

\section{Phototrophic Organisms Identification}

The main types of communities that colonize the cave surfaces were identified near the light sources on the basis of their microscopic and macroscopic features. This approach was chosen in order to be easily reproduced by future cave management. It was assumed that the new lights were placed in the same locations as the previous installation. Samples were acquired in the monitoring sites shown in Figure 2 a (sites $\mathrm{Zi}-1$ to $\mathrm{Zi}-6$ ). The phototrophic community types were identified on the basis of samples collected along transects that involve multiple lights. These were designed by randomly selecting six lamps at each site. At each sampling site, four samples were acquired at a distance of about $1 \mathrm{~m}$ from each lamp in different directions, north, south, east, and west. Samples were acquired by scraping off $2 \mathrm{~cm}^{2}$ of surface at each sampling site and near the cave entrance. It is important to stress that the entrance is the only part of the cave that can be reached by solar radiation, therefore, a different flora is expected in this area. The presence of vermicular formations, the color and size of algal colonization, and the moisture content of the substrate were recorded for each sample. Each sample was collected using a disposable sterile spatula and stored separately in a sterilized plastic tube until its analysis in the laboratory one hour later. Samples were examined using a LEICA optical microscope (maximum magnification $1000 \times$ ) to detect the presence of fungal mycelium, examine the morphology and frequency of the algal component, and distinguish between green algae and cyanobacteria. Algae were determined only at phyla taxonomic level. Bryophytes and pteridophytes were determined according to Pedrotti (2001) and Prelli and Boudrie (2001).

\section{Community Distribution in Response to Light INTENSITY}

The distribution of the phototrophic community types previously identified was analyzed with respect to the light intensity measured with a luxmeter ISO-Tech ILM 350. Light intensity was acquired in a perpendicular direction with respect to the highest part of the cave in order to consider possible shadows cast in some parts of the transects. Data on light intensity were collected along thirty transects using the luxmeter. Each transect was designed to span two light sources. The transect length varied from 5 $\mathrm{m}$ (minimum distance between lights) to $15 \mathrm{~m}$ (maximum distance between lights). Each transect had its origin at one light source and covered the adjacent lateral surfaces up to the ceiling surface of the cave until its end in the next light source (Fig. 2c). Each transect was acquired in locations characterized by almost constant microclimatic conditions. The transects were designed in the $\mathrm{Zi}-2$ through $\mathrm{Zi}-5$ sites (Fig. 2a), where temperature remains almost stable over the year and relative humidity is over $90 \%$. The community type, the height from the floor, the distance from the radiation source, and the intensity of the incident light were recorded every $30 \mathrm{~cm}$ along each transect.

\section{Composition of Vermicular Formations}

Microbiological surveys were performed to investigate the composition of vermicular formations. Samples of vermicular formations and soil were collected in seven sites, 
labelled Zi-0 through Zi-6 in Fig. 2a, within the cave. The samples were collected using sterile equipment, such as disposable spatulas and fiber dracon swabs. An aliquot of the samples was introduced directly in liquid medium (tryptose broth), and another aliquot was sown directly onto solid malt agar, Sabouraud, and Triple Sugar Iron. Moreover, pool and dripping water samples were collected in the $\mathrm{Zi}-2$ site using sterilized pipettes. Water samples were filtered using $47 \mathrm{~mm}$ millipore filter with $0.45 \mu \mathrm{m}$ porosity. Standard methods were followed for the identification of bacteria and fungi (Bailey and Scott, 1974; Barnett and Hunter, 1998). It was carried out by the macroscopic examination of colonies (color, gloss, forms), by detection of the microscopic features of bacteria (Gram stain, presence of capsule, morphology, motility, size), and biochemical typing on Triple Sugar Iron in Methyl Red-liquid Voges Proskauer, nitrate liquid medium, phenylalanine agar, citrate agar, urea liquid medium.

A ZEISS UltraLux microscope and a ZEISS Axioscope microscope were used for the morphological analysis. A DCM500 digital imager was used to capture and store images. Fungi were identified on the basis of visible spore and hyphal morphology and color. Both classical (Bailey and Scott, 1974) and numerical methods (Holt, 1994; Goodall, 1966) were used for tests on each colony. Triple Sugar Iron (TSI), TSI gas, TSI butt, TSI slant, $\mathrm{H}_{2} \mathrm{~S}$, Sellers, fluorescent slant, citrate, catalase, indole, methyl red, phenylalanine, urease, Voges Proskauer, nitrate and nitrite reduction, and oxidase reactions were used for bacterial typing and saved in a database for use in future tests. Fungi of genus Geotrichum were identified on the basis of visible rectangular arthrospores, in the germinative state (Bailey and Scott, 1974).

Numerical methods (Holt, 1994; Jaccard, 1912) optimally require a minimum of thirty tests to determine genus, and possibly as many as one hundred tests to determine species. The morphometric and biochemical data is generally compared to large databases of bacterial data to attempt automated identification by scoring each colony with the Jaccard index. However, in this case, the Sokal modification (Sneath and Sokal, 1973) to the Jaccard index, which ignores negative test results, is more suitable for biome comparison and study of metabolic processes within a biome (Goodall, 1966), as well as for mapping the flow of metabolites on cave surfaces. We carried out thirty tests to investigate the metabolic environment and to make a determination of similarity. Sokal scores were calculated from the morphometric and metabolic tests on the bacteria collected in the Zinzulusa in 1999 (Onorato et al., 1999) and to make a similarity comparison with 2009. Test results and images were stored in a database and processed to provide a comparison with other caves. The similarity index can provide a measure of change in metabolic profiles within the biomes caused by the changes made in illumination.

\section{RESUlts AND Discussion}

The Grotta Zinzulusa microclimate is consistent with other single-entrance caves, with large temperature and relative-humidity variations near the entrance and smaller variations internally. These variations depend on the position inside the cave and the season (Fig. 3). Only the first measurement sites are influenced by the outdoor exchanges, while starting from the Trap (point 4) the difference is lower and the temperature profile is more stable within the site during the monitoring period.

When the thermal inversion occurs, from November to May, the average cave temperature is $17.3 \pm 2.6{ }^{\circ} \mathrm{C}$, while the average external temperature is $14.1 \pm 1.3{ }^{\circ} \mathrm{C}$. In general, the thermal gradient between the cave and the exterior atmosphere is between 3 and $4{ }^{\circ} \mathrm{C}$ (Fig. 3b).

The maximum temperature gradient between the outside air and points in the cave occurs up to the Canopy (point 5 in Fig. 2a), approximately in the middle part of the cave. From the Trap (point 4 in Fig. 2a) to the Waterfall (point 6 in Fig. 2a) there is a gradient of at least $1{ }^{\circ} \mathrm{C}$. After the Crypt (point 7 in Fig. 2a) no difference is found in both seasons (Fig. 3a).

Humidity within Grotta Zinzulusa tends to remain high at all the monitoring sites 1 to 10 in the cave, with values between $90 \%$ and $100 \%$, showing small differences over time. The logger at point 1 recorded the most variation and the lowest relative humidity, with values around $80 \%$. The saturation level is quite often reached inside the cave, and in general, an equilibrium is achieved between speleothems, ceiling areas, and surrounding air.

We now describe the outcomes related to the algal and micro-biological communities of Grotta Zinzulusa. The response of phototrophic organisms to light intensity revealed an abundant cryptogam flora present within $5 \mathrm{~m}$ from the entrance, where the light intensity and the solar radiation are reduced by about $80 \%$. It primarily consists of lichens, bryophytes (mainly unidentified protonema and mosses such as Rhynchostegiella tenella and Eucladium verticillatum), gametophytes, and sporophytes of pteridophytes such as Adiantum capillus-veneris. E.verticillatum is responsible for the formation of organogenic concretions that grow from the dripping ceilings oriented towards the outside of the cave as phototropic growth. Bryophyte protonema and small lichens are only present occasionally, while algal communities consistently spread over artificially-lit surfaces. A dense presence of bacteria and fungi was detected.

Four phototrophic community types (Fig. 4 and Table 1) have been identified during the transects (Fig. 2c) carried out to analyze the response to light intensity. They are distinguished by macroscopic characteristics detectable with the naked eye, so this identification can be useful for rapidly detecting future changes in their distribution. From the entrance of the cave to the other locations, the relative frequency of the algal component increases. A major algal component can be observed passing from the community

Journal of Cave and Karst Studies, December 2015 • 137 

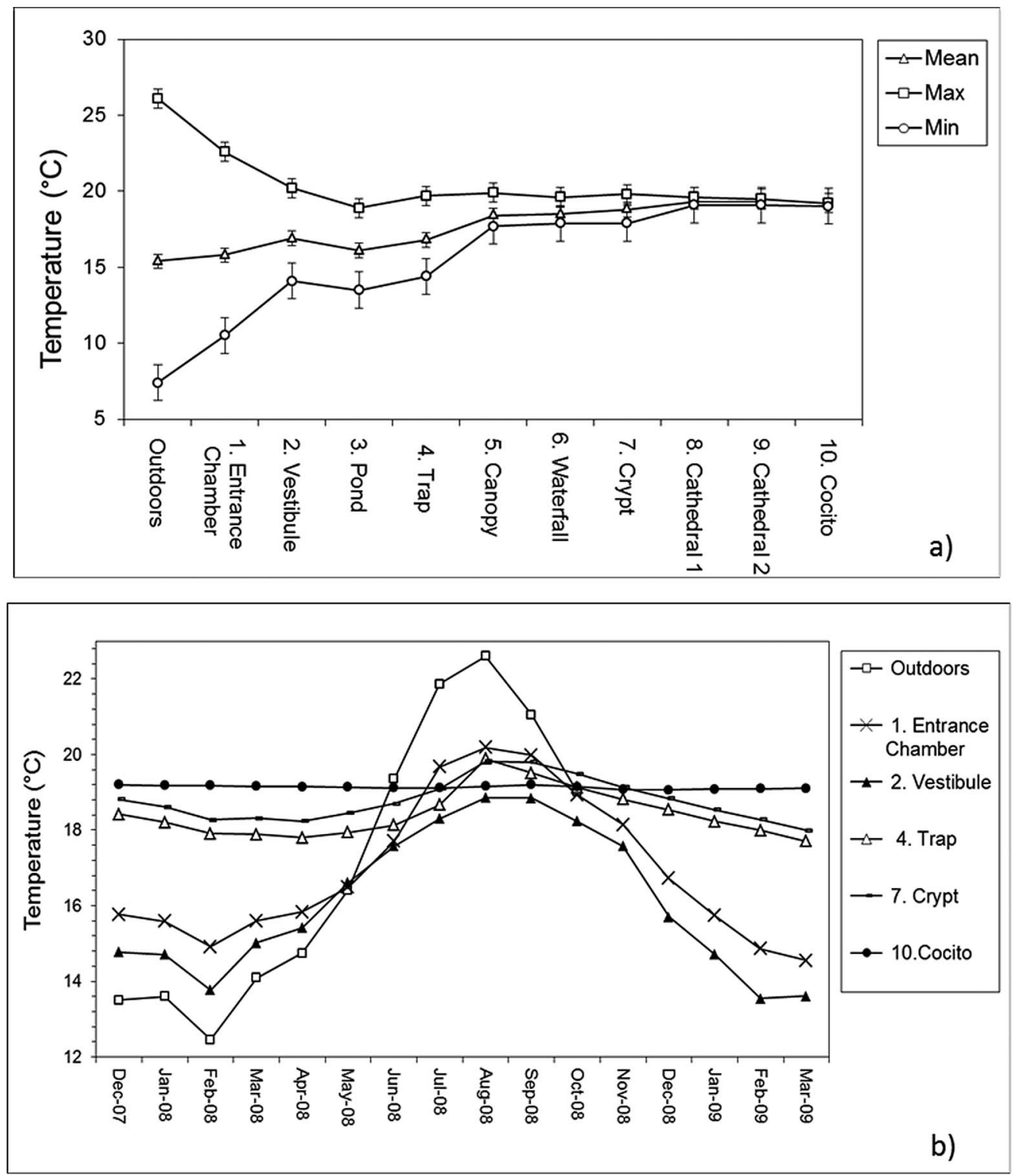

Figure 3. a) Average, maximum, and minimum air temperature $\left({ }^{\circ} \mathrm{C}\right)$ in the period December 2007-December 2009 at the measurement points of Fig. 2a. b) Air temperature over the measurement period outside and at some named points inside the cave. The error bars indicate the uncertainty of the given values, they refer to the instrumental error of the measurements. Data collected by the University of Salento and provided with publishing permission by the Castro Municipality.

types 1 and 2 to the community types 3 and 4 , in relation to the light gradient. Types 3 and 4 also respond selectively to the substrate wetting, and, in particular, the community type 4 requires a wet substrate.

The response to the light intensity is not monotonic. Fig. 5 shows the frequency distributions of the four community types versus the photon flux density (PPFD) obtained by combining data from all the transects. The community types are distributed selectively according to the light intensity around the lights. In particular, the community type 1 shows a peak at a flux of $0.3 \mu \mathrm{mol} \mathrm{m} \mathrm{m}^{-2} \mathrm{~s}^{-1}$, while at other intensities, its presence is much lower. The community types 2 and 3 have their ecological optimum in the short interval between 0.1 and $0.3 \mu \mathrm{mol} \mathrm{m} \mathrm{m}^{-2} \mathrm{~s}^{-1}$, and their presence is inhibited at both minor and major light intensities. The community type 4 is the most heliophilous, since it is distributed in a light range between 0.1 and $0.8 \mu \mathrm{mol} \mathrm{m} \mathrm{m}^{-2} \mathrm{~s}^{-1}$. The community types 3 and 4 show algae growth at light intensity as low as $0.33 \mu \mathrm{mol}$ $\mathrm{m}^{-2} \mathrm{~s}^{-1}$, showing that algae in caves can survive at photon flux densities in the range of 0.5 to $1 \mu \mathrm{mol} \mathrm{m} \mathrm{m}^{-2}$ $\mathrm{s}^{-1}$. Finally, it is worth noting that all community types have a reduced growth to light intensities higher than $0.8 \mu \mathrm{mol} \mathrm{m}{ }^{-2} \mathrm{~s}^{-1}$. 


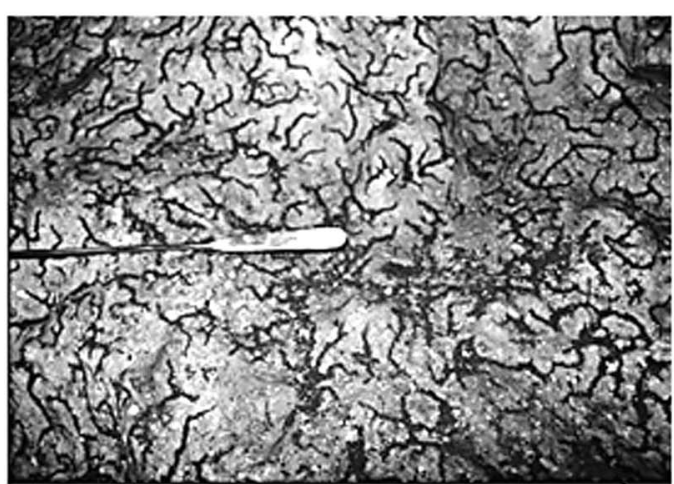

a)

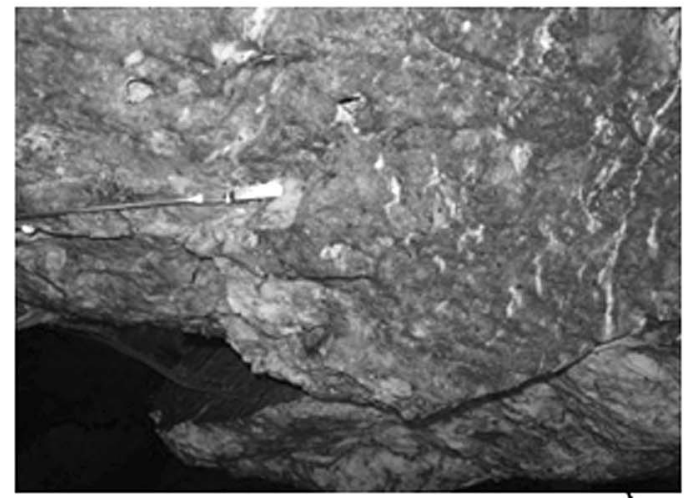

c)

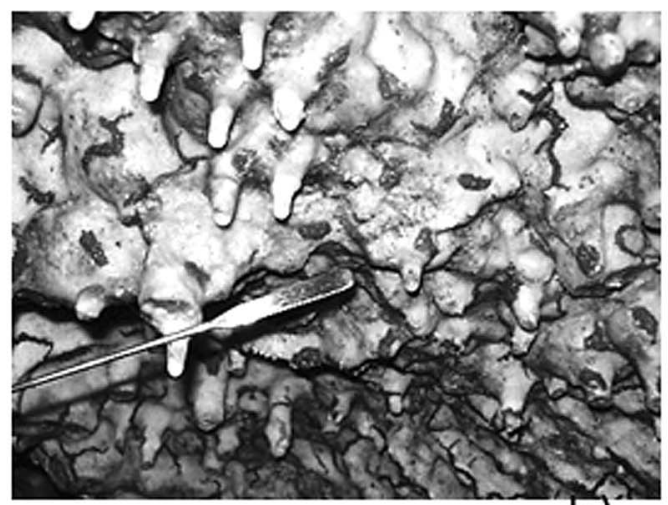

b)

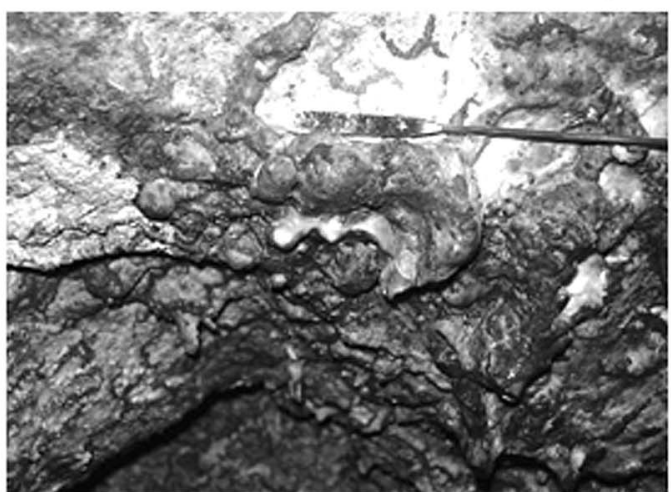

d)

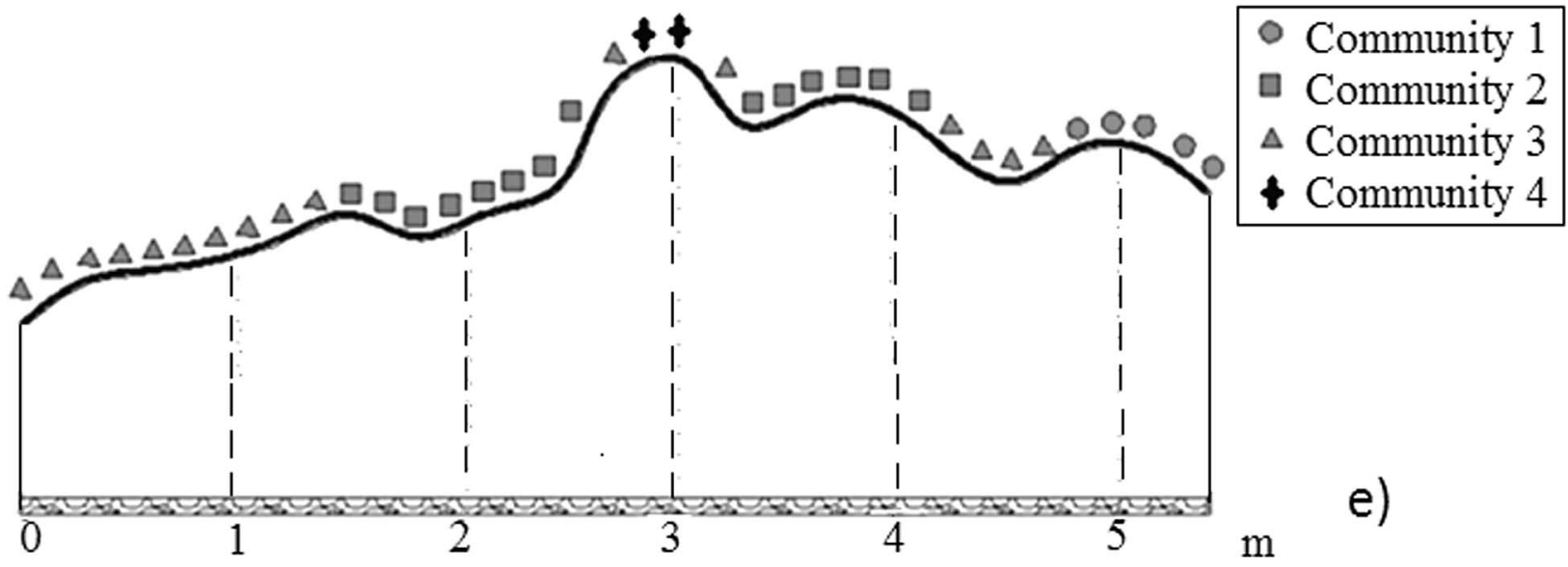

Figure 4. Community types (Table 1) living in Grotta Zinzulusa: a) type 1, b) type 2, c) type 3, d) type 4. e) A profile of of a 5-m transect two lamps, $h$ the height measured from the cave floor.

Microscopic analysis of the vermicular formations has identified a biotic component mainly composed of bacteria and protozoa with a predominance of fungi (septate hyphae, spores). Moreover, elements of animal origin are found in the samples collected throughout the cave, including excreta and residuals of Isopoda, Diptera, and Lepidoptera scales. Lint has also been found in the collected material, and its origin is due to the tourist presence.

We identified Geotrichum candidum (Fig. 6), Mucor troglophilus, and Aspergillus sp. pl. in the vermicular formations. Geotrichum has cells which are fairly characteristic, with dimensions of 4 by $8 \mu \mathrm{m}$. It produces a thick mucus capable of aggregating clay particles (de Hoog et al., 1986). Biological activity of Geotrichum was detected by the production of the metabolic lactic and succinic acids. Geotrichum tends to develop linearly according to a dendritic pattern that suggests a role in the vermicular formations. Comparing the vermicular formation organisms with other cave collections and identification charts (Cornish-Bowden, 2012), an unsatisfactory classical identification profile has

Journal of Cave and Karst Studies, December 2015 • 139 
Table 1. Main features of the phototrophic community types living in the lighted part of Grotta Zinzulusa.

Community

type $\quad$ Microscopic examination

Substrate

Macroscopic appearance

$1 \quad$ Abundant fungal mycelium and inorganic components.

Algal cells almost absent.

$2 \quad$ Fungal mycelium and unicellular algae

(Cyanophytes).

3 Abundant fungal mycelium, unicellular and multicellular threadlike algae

(Cyanophytes).

Clusters of small rounded algal cells

(Cyanobacteria).

4 Abundant Cyanophytes.

Clusters of rounded algal cells

(Cyanobacteria).

Fungal mycelium relatively less frequent.
Dry or slightly wet. Vermicular formations. No green film.

Dry or slightly wet.

Dry or slightly wet.

Vermicular formation and bright green isolated stains.

Vermicular formations and bright green confluent stains.

Wet.

Gelatinous and dark green films. been obtained. Those fungi are capable of development via different types of interactions with other organisms by using their versatile metabolic pathways (Lazzari, 1966).

The bacterial taxa isolated in the samples are Shigella sp., Campylobacter concisus, Enterobacter aerogenes, Enterobacter hafniae, Pseudomonas sutzeri, Pseudomonas aeruginosa, Ancalomicrobium adetum, Klebsiella pneumoniae, Moraxella lacunata, Moraxella osloensis, Yersinia sp., Providencia stuartii, Bacillus schlegelii, Bacillus polpilliae, Kingella kingie (= Moraxella kingie), and Psychrobacter phenylpyruvicus (= Moraxella phenylpyruvica). They were almost uniformly distributed within the sampling sites.
Results of the computational comparison between the data of 1999 and 2009 reveal a Sokal index of 0.39, suggesting that some changes might have taken place between collections. Figure 7 and Table 2 present the metabolite information from the bacterial tests to identify the predominate chemistry in the different biomes. Table 2 shows that the large amount of nitrate observed at the $\mathrm{Zi}-4$ site could be coupled to vegetal activity, but could also be related to light intensity. The table shows decreases in the later data in oxidase and Vogues-Proskauer (utilizing the butylene glycol pathway producing acetoin) and a reduction of motile organisms to $25 \%$ of 1999 levels. Also, there is no remaining urea metabolism

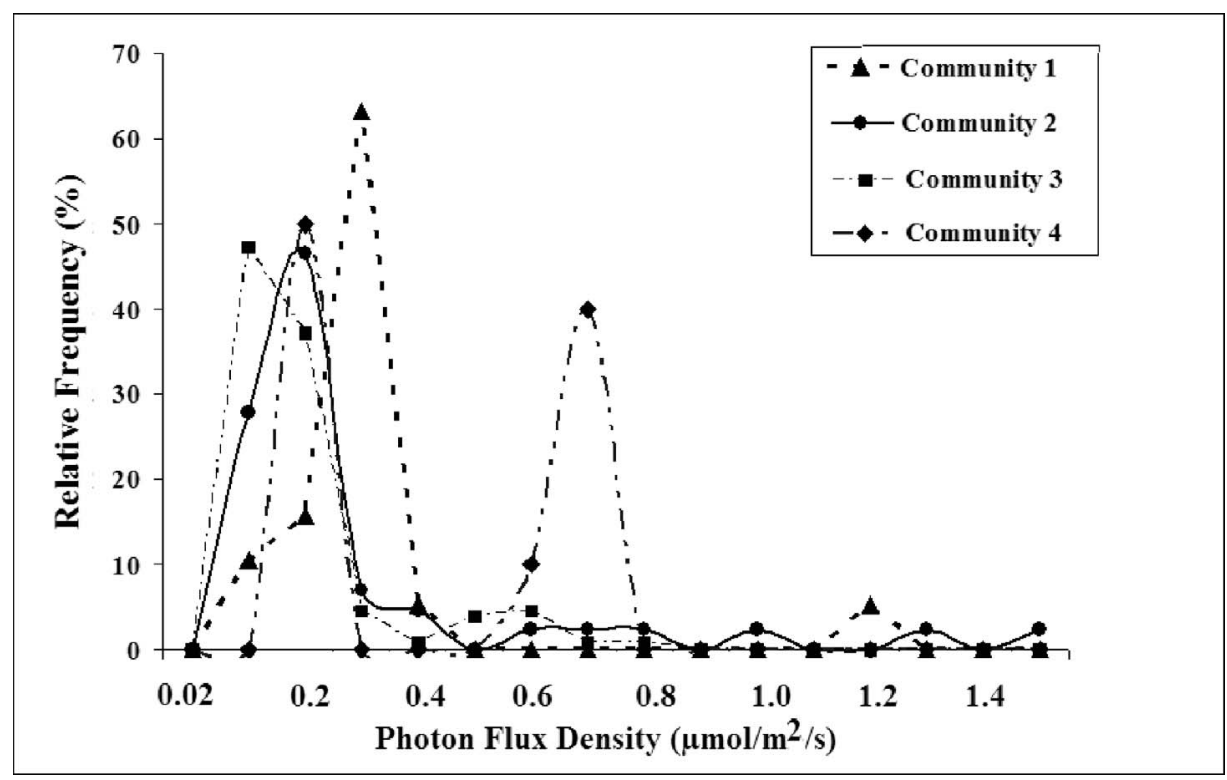

Figure 5. Relative frequency distribution of the four communities versus the light intensity, developed by combining data from all transects. Relative frequency is the percentage of the identified communities versus light intensity. The total of $100 \%$ is verified in the sum of the frequencies of each community (community 1, 2, 3, 4) with light intensity. 


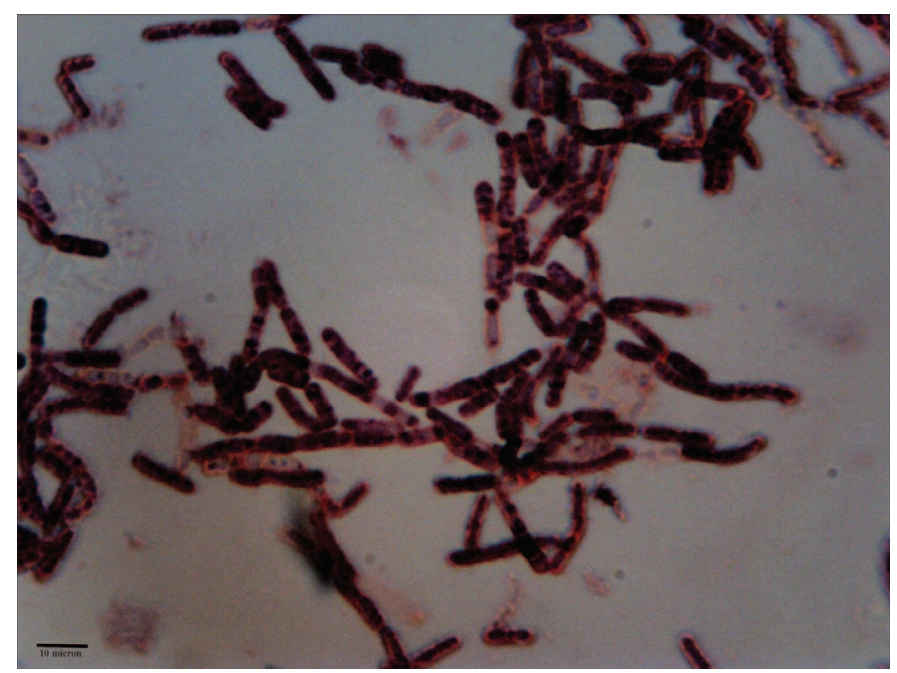

Figure 6. Geotrichum candidum (Gram stain, scale bar is $10 \mu \mathrm{m}$ ).

by vermiculation bacteria, possibly due to the change to LED lighting. Evidence of nitrogen fixation from nitrate is seen in low-light areas even though, according to Dunstan et al. (1982) and de Freitas and Schmekal (2003), this activity should be inhibited in darkness. It is also interesting to observe that very little nitrite reduction to $\mathrm{N}_{2}$ is taking place (Table 2 and Fig. 7), supporting the hypothesis of nitrite consumption by vegetation or fungi rather than by bacteria.

In the light range between 0.1 and $0.3 \mu \mathrm{mol} \mathrm{m} \mathrm{m}^{-2} \mathrm{~s}^{-1}$, which is the ecological optimum of the community types 2 and 3, the maximum level of metabolic activity is observed (Fig. 7). Of course, while there seems to be some correlation between photon flux and sugar metabolism (Fig. 7), there could be several other factors at play. More study is needed in this direction. Moreover, there was a doubling of citrate utilization, which might indicate mutations in E. coli (Lenski, 2000), and indole production, which reinforces the need to remediate the sewage influx problem with Zinzulusa.

A comparison of the microbiological component of Grotta Zinzulusa with the microbiological component of other caves is depicted in Figure 8. Among the tested caves, the most dissimilar caves, corresponding to score values close to zero, were the closed-to-visitors Horsethief Cave, Wyoming, (Sokal score 0.015) and a cave explored in Canada with spherical ceiling pendants having Geotrichum sp. These caves are rather dry caves compared to Zinzulusa. On the other end of the scale, Snaggletooth Cave, a partially restricted cave in New York State, scored highest at 0.47 ; a value justified by the fact that this cave is subject to seepage of treated sewage. The remainder are mostly caves with influx consisting of woodland drainage, all of which represent animal activity in bacterial content.

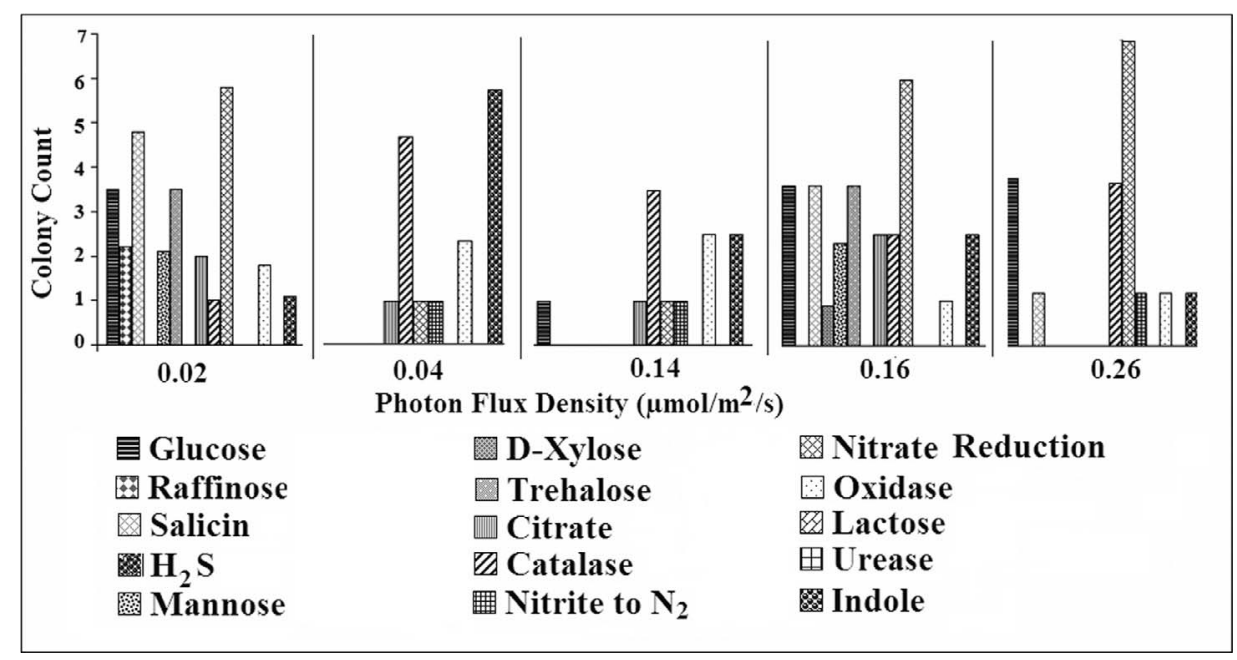

Figure 7. Metabolic activity of the bacterial component in the community types in Grotta Zinzulusa versus the light intensity. 
Table 2. Metabolic characteristics of the bacterial component of the samples collected during the surveys of 1999 (Camassa and Febbroriello, 2003) and 2009.

\begin{tabular}{lcccccc}
\hline Metabolome & \# 1999 & \% POS 1999 & \% NEG 1999 & \# 2009 & \% POS 2009 & \% NEG 2009 \\
\hline TSI GAS & 14 & 0 & 100 & 33 & 0 & 100 \\
pH in V-P broth $<6$ & 14 & 14.3 & 85.7 & 36 & 38.9 & 61.1 \\
Utilization of citrate & 14 & 14.3 & 85.7 & 28 & 25 & 75 \\
Gram Positive (young cultures) & 7 & 42.8 & 57.1 & 23 & 52.2 & 47.8 \\
Catalase & 10 & 50 & 50 & 27 & 55.6 & 44.4 \\
Indole & 14 & 0 & 100 & 28 & 28.6 & 71.4 \\
Motility & 7 & 42.8 & 57.1 & 8 & 12.5 & 87.5 \\
Oxidase & 6 & 83.3 & 16.7 & 27 & 44.5 & 55.5 \\
Phenylalanine deaminase & 6 & 0 & 100 & 20 & 0 & 100 \\
TSI & 14 & 57.1 & 42.8 & 33 & 51.5 & 48.5 \\
TSI BUTT & 6 & 0 & 100 & 16 & 0 & 100 \\
TSI H2S & 14 & 0 & 100 & 33 & 0 & 100 \\
TSI SLANT & 8 & 0 & 100 & 16 & 0 & 100 \\
Urease & 14 & 7.2 & 92.8 & 20 & 0 & 100 \\
Voges Proskauer & 13 & 7.6 & 92.3 & 35 & 0 & 100 \\
Nitrate reduction & 14 & 64.3 & 35.7 & 36 & 75 & 25 \\
TSI GAS & 14 & 0 & 100 & 33 & 0 & 100 \\
\hline
\end{tabular}

Many factors can favor a long-term colonization, among them a high relative humidity, relatively stable temperature, a water $\mathrm{pH}$ close to neutrality, and other features influencing the attachment of bacteria, such as micro-roughness, substratum chemistry and $\mathrm{pH}$, and fluid-dynamics. As an example, a large presence of bacteria is observed in the closed-tovisitors Lascaux Cave (Cunningham et al., 1995) and in the Maltravieso (Arroyo et al., 1997) and Altamira Caves (Laiz et al., 1999), where cyanobacteria and faecal indicators appeared in abundance, especially in dripping waters (Northup et al., 2003). Even though these measurements have helped to identify caves with metabolic similarity, the generally low scores clearly suggest that every cave environment is unique and worth a detailed study and protection.

\section{Conclusions}

This paper represents the first assessment of the microclimatic and microbial characterization of Grotta Zinzulusa in southeastern Italy. We performed surveys to analyze both the distribution of the phototrophic organisms in response to light intensity and the microbiological component of vermicular formations. The outcomes of this research contribute to the knowledge of lampenflora contamination after lighting replacement by LEDs. The environmental monitoring performed in the cave revealed that the light sources contribute to the development of a complex system of communities inside the cave.

The replaced tungsten lamps were not suitable for cave preservation, as they increased temperature and decreased humidity. The new LED system has a smaller impact on the cave microclimate, emits light of natural appearance, consumes less electricity, and has no IR spectrum. Another advantage is to have a lower irradiance with high illuminance values that create contrast with the illuminated objects. Tourist attendance is contributing to the introduction of live microorganisms that can persist in the cave environment, such as fungi and bacteria. To prevent the introduction of microbes, a disinfection barrier can be installed outside the cave. Among the different species, photosynthetic algae appeared to be dependent on light intensity, but in the presence of available nutrients, an unsuitable light quality for lampenflora growth can slow their proliferation slightly, but only within a short period of time.

The study assessed the presence and identification of four principal phototrophic communities with a preference for low light intensities. The complex lampenflora algae is ubiquitous. Furthermore, a dense diffusion of microbial forms, mainly represented by Geotrichum, was found spreading in the cave, with the production of metabolic lactic and succinic acids that are responsible for superficial bioerosion. To reduce lampenflora growth, the lighting regime should be restricted. Specific actions could be taken to control the diffusion of communities inside the cave. For example, the open hours of the cave or the hours during which the lights are turned on could be reduced. A limit of people entering the cave or further spatial restrictions could be also established.

The results of this study are intended to be used to support the development of a rigorous monitoring program for the on-going management of Grotta Zinzulusa. A long-term program is needed to monitor lampenflora growth, the microclimate, and environmental. These results can be a basis for the establishment of guidelines for the use of the cave system as a natural asset, including maximum number of tourists and frequency of visits. They might also serve as a starting point for future investigations, as well as for comparisons with other caves. 


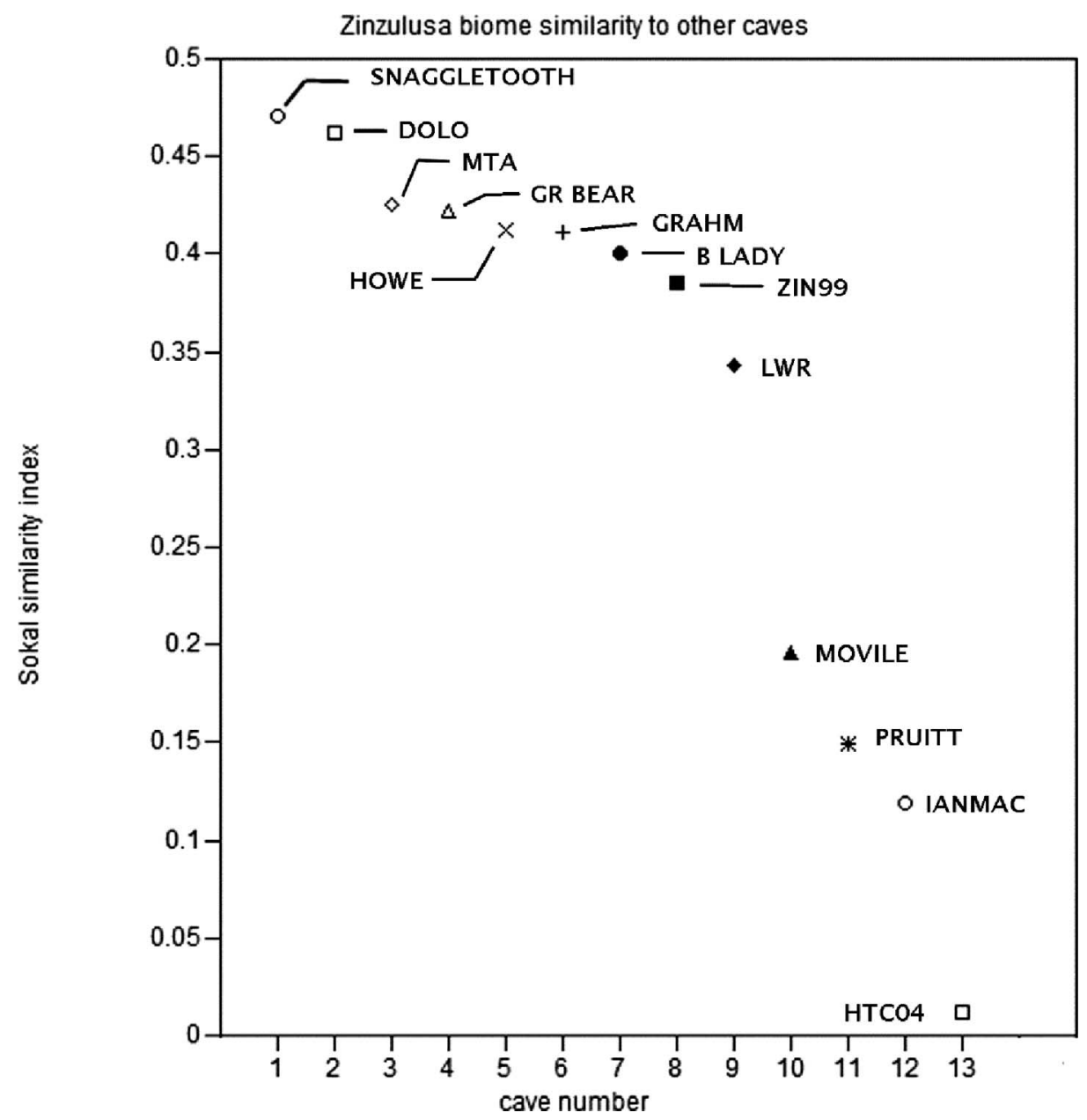

Figure 8. Comparison of Sokal index of similarity with other caves: Snaggletooth Cave (SNAGGLETOOTH), NY, USA, treated sewer seepage; Dolo Cave (DOLO), MA, USA, woodland surface stream insurgence; Mount Anthony Cave (MTA), VT, USA, woodland surface stream insurgence; Growling Bear (GR BEAR) Cave, MA, USA, underground spring; Howe Caverns, NY, USA, tourist cave; Grahm Mountain Cave (GRAHM), NY, USA, bat hibernaculum (B LADY), CT, USA, woodland swamp drainage; Zinzulusa, 1999 samples (ZIN99); Lake of the White Roses (LWR), Lechuguilla Cave, NM, USA, sulfur cycle with minimum surface water influx; Movile Cave (MOVILE), Romania, $\mathrm{H}_{2} \mathrm{~S}$, underwater samples; Buford Pruitt (PRUITT) cave samples, FL, USA, rarely entered; Ian McKenzie (IANMAC) cave samples, Canada, dry mountain cave ceiling pendants, restricted access; Horsethief Cave (HTC04), WY, USA, mountainous cave area.

\section{ACKNOWLEDGEMENTS}

The authors thank the Castro Municipality that provided permission to publish the microclimatic data, as well as other information about the cave. They are grateful to Massimo Luggeri and Ninì Ciccarese for technical support and to Michele Aleffi for mosses identification. Thanks are also due to Peter Gattinesi and Robert Kenny for proofreading.

The authors participated in establishing research design, methodology, and analysis. In particular, D. D'Agostino contributed to microclimatic and light intensity surveys, $\mathrm{L}$. Beccarisi and D. D'Agostino cooperated to the photophilous communities analysis, and M.M. Camassa and P. Febbroriello collaborated on microbiological surveys.

\section{REFERENCES}

Aley, T., 2004, Tourist caves: algae and lampenflora, in Gunn J, ed., Encyclopedia of Caves and Karst Science: New York, Fitzroy Dearborn, p. 733-734.

Arroyo, G., Arroyo, I., and Arroyo, E., 1997, Microbiological analysis of Maltravieso cave (Caceres) Spain: International Biodeterioration and Biodegradation, v. 40, no. 2-4, p.131-139. doi:10.1016/S0964-8305(97) 00039-5.

Bailey, W.R., and Scott, E.G., 1974, Diagnostic Microbiology: A Textbook for the Isolation and Identification of Pathogenic Microorganisms, fourth edition: St. Louis, Mosby, p. 363-403.

Baker, A., and Genty, D., 1998, Environmental pressures on conserving cave speleothems: effects of changing surface land use and increased cave tourism: Journal of Environmental Management, v. 53, p. 165-175. doi:10.1006/jema.1998.0208.

Barnett, H.L., and Hunter, B.B., 1998, Illustrated Genera of Imperfect Fungi, fourth edition: St. Paul, APS Press, 218 p.

Journal of Cave and Karst Studies, December 2015 • 143 
Bastian, F., and Alabouvette, C., 2009, Lights and shadows on the conservation of a rock art cave: The case of Lascaux Cave: International Journal of Speleology, v. 38, p. 55-60. doi: 10.5038/1827-806X.38.1.6.

Belson, C., 1999, Karst Waters Institute's second annual top ten list of endangered karst ecosystems: KWI Conduit, v. 7. no. 1-2, 5 p., http://www. karstwaters.org/conduit/vol7nol/karst10.htm [accessed January 2015]

Camassa, M.M., 2003, Food resources, in Gunn, J., ed., Encyclopedia of Caves and Karst Science: New York, Fitzroy Dearborn, p. 367-370.

Camassa, M.M., and Febbroriello, P., 2003, Le foval della Grotta Zinzulusa in Puglia (SE-Italia): Thalassia Salentina, v. 26 suppl., p. $207-$ 218. doi:10.1285/i15910725v26supp207. [v. 26 was published in 2002, v. 26 supplement in 2003 ]

Ciccarese, G., and Pesce, G., 1999, La Zinzulusa: 200 anni dopo: Thalassia Salentina, v. 23 suppl., p. $79-88$.

Cigna, A.A., 2004, Climate of Caves: in Gunn, J., ed., Encyclopedia of Caves and Karst Science: New York, Fitzroy Dearborn, p. 726-730.

Cornish-Bowden, A., 2012, Fundamentals of Enzyme Kinetics, fourth edition: Weinheim, Wiley-Blackwell, $510 \mathrm{p}$.

Cunningham, K.I., Northup, D.E., Pollastro, R.M., Wright, W.G., La Rock, E.J., 1995, Bacteria fungi and biokarst in Lechuguilla Caves Carlsbad Caverns National Park New Mexico: Environmental Geology, v. 25 , p. 2-8.

de Freitas, C.R., and Littlejohn, R.N., 1987, Cave climate: Assessment of heat and moisture exchange: Journal of Climatology, v.7, p. 553-569. doi:10.1002/joc.3370070604.

de Freitas, C.R., and Schmekal, A., 2003, Condensation as a microclimate process: Measurement, numerical simulation and prediction in the Glowworm Cave, New Zealand: International Journal of Climatology, v. 23, p. 557-575. doi:10.1002/joc.898.

de Hoog, G.S., Smith, M.T., and Guého, E., 1986, A Revision of the Genus Geotrichum and its Teleomorphs: Utrecht, CBS-KNAW Fungal Biodiversity Centre, Studies in Mycology 29, $131 \mathrm{p}$.

Dobat, K., 1998a, Flore (lichens, bryophytes, pteridophytes, spermatophytes), in Juberthie, C., and Decu, V., eds., Encyclopaedia Biospeologica: Moulis, Société Biospéologie, vol. 2, p. 1311-1324.

Dobat, K. 1998b, Flore de la lumière artificielle (lampenflora - maladie verte), in: Juberthie, C., and Decu, V., eds., Encyclopaedia Biospeolologica: Moulis, Société Biospéologie, vol. 2, p. 1325-1335.

Dunstan, R.H., Kelley, B.C, and Nicholas, D.J.D., 1982, Fixation of dinitrogen derived from denitrification of nitrate in a photosynthetic bacterium, Rhodopseudomonas sphaeroides forma $\mathrm{sp}$. denitrificans: Journal of Bacteriology, v. 150, no. 1, p. 100-104.

Faimon, J., Štelcl, J., Kuběová, S., and Zímak, J., 2003, Environmentally acceptable effect of hydrogen peroxide on cave "lamp-flora", calcite speleothems and limestones: Environmental Pollution, v. 122, p. 417-422. doi:10.1016/S0269-7491(02)00309-3.

Fong, D.W., 2011, Management of subterranean fauna in karst, in van Beynen, P.E., ed., Karst Management: Dordrecht, Springer, p. 201-224. doi:10.1007/978-94-007-1207-2_9.

Gamble, D.W., Dogwiler, J.T., and Mylroie, J., 2000, Field assessment of the microclimatology of tropical flank margin caves: Climate Research, v. 16 , p. 37-50. doi: $10.3354 / \mathrm{cr} 016037$.

Gillieson, D., 1996, Caves: Processes, Development, Management: Oxford, Blackwell, $324 \mathrm{p}$.

Gillieson, D.S., 2011, Management of caves, in van Beynen, P.E., ed., Karst Management: Dordrecht, Springer, pp. 141-158. doi:10.1007/ 978-94-007-1207-2_6.

Goodall, D.W., 1966, Numerical taxonomy of bacteria-Some published data re-examined: Microbiology, v. 42, p. 25-37. doi: 10.1099/ 00221287-42-1-25.

Hamilton-Smith, E., 2004, Show caves, in Gunn, J., ed., Encyclopedia of Caves and Karst Science: New York, Fitzroy Dearborn, p. 726-730.

Holt, J.G., 1994, Bergey's Manual of Determinative Bacteriology, ninth edition: Hagerstown, Lippincott Williams \& Wilkins, p. 787.

Jaccard, P., 1912, The distribution of the flora in the alpine zone: New Phytologist, v. 11, p. 37-50, doi:10.1111/j.1469-8137.1912.tb05611.x.

Jurado, V., Fernandez-Cortes, A., Cuezva, S., Laiz, L., Cañaveras, J.C, Sanchez-Moral, S., and Saiz-Jimenez, C., 2009, The fungal colonisation of rock-art caves: Experimental evidence: Naturwissenschaften, v. 96, p. 1027-1034. doi:10.1007/s00114-009-0561-6.

Laiz, L., Groth, I., Gonzalez, I., and Saiz-Jimenez, C., 1999, Microbiological study of the dripping waters in Altamira cave (Santillana del Mar Spain): Journal of Microbiological Methods, v. 36, p. 129-138. doi:10.1016/S0167-7012(99)00018-4.
Lazzari, A., 1966, La grotta Zinzulusa presso Castro (Lecce., osservazioni geomorfologiche con notizie storico-bibliografiche e due appendici): Annali del Pontificio Istituto Superiore di Scienze e Lettere "S. Chiara", p. 1-63.

Lenski, R.E., 2000, Source of founding strain, web site of the long-term evolution experiment, Michigan State University, http://myxo.css. msu.edu/ecoli/strainsource.html [accessed 18 June 2008].

Mulec, J., 2012, Lampenflora, in White, W.B., and Culver, D.C., eds., Encyclopedia of Caves: Amsterdam, Elsevier, p. 451-456.

Mulec, J., 2014, Human impact on underground cultural and natural heritage sites, biological parameters of monitoring and remediation actions for insensitive surfaces: Case of Slovenian show caves: Journal of Nature Conservation, v. 22, p. 132-141. doi:10.1016/j.jnc.2013.10.001.

Mulec, J., and Kosi, G., 2009, Lampenflora algae and methods of growth control: Journal of Cave and Karst Studies, v. 71, no. 2, p. 109-115.

Mulec, J., Kosi, G., and Vrhovšek, D., 2007, Algae promote growth of stalagmites and stalactites in karst caves (Škocjanske jame Slovenia): Carbonates and Evaporites, v. 22, no. 1, p. 6-9. doi:10.1007/BF03175841.

Mulec, J., Kosi, G., and Vrhovšek D., 2008, Characterization of cave aerophytic algal communities and effects of irradiance levels on production of pigments: Journal of Cave and Karst Studies, v. 70, no. 1, p. 3-12.

Northup, D.E., Barns, S.M., Yu, L.E., Spilde, M.N., Schelble, R.T., Dano, K.E., Crossey, L.J., Connolly, C.A., Boston, P.J., Natvig, D.O., and Dahm, C.N., 2003, Diverse microbial communities inhabiting ferromanganese deposits in Lechuguilla and Spider caves: Environmental Microbiology, v. 5, p. 1071-1086. doi:10.1046/j.1462-2920.2003.00500.x.

Northup, D.E., and Lavoie, K.H., 2001, Geomicrobiology of caves: A review: Geomicrobiology Journal, v. 18, no. 3, p. 199-222. doi:10. 1080/01490450152467750.

Nováková, A., 2009, Microscopic fungi isolated from the Domica Cave system (Slovak Karst National Park, Slovakia). A review: International Journal of Speleology, 38, no. 1, 71-82. doi:10.5038/1827806X.38.1.8.

Olson, R., 2006, Control of lamp flora in developed caves, in Hildreth-Werker, V., and Werker, J.C, eds., Cave Conservation and Restoration: Huntsville, National Speleological Society, p. 343-348.

Onorato, R., Denitto, F., and Belmonte, G., 1999, Le grotte marine del Salento: classificazione, localizzazione e descrizione: Thalassia Salentina, v. 23, p. 67-116. doi:10.1285/115910725v23p67.

Parenzan, P., 1963, Concerning the clayish-slimy formations termed vermicular: Cascade Caver, v. 2, no. 7, 8 p.

Parise, M., 2011, Some considerations on the show cave management issues in southern Italy, in van Beynen, P.E., ed., Karst Management: Dordrecht, Springer, p. 159-167. doi:10.1007/ 978-94-007-1607-2_7.

Pedrotti, C.C., 2001, Flora dei muschi d'Italia, parte 1: Sphagnopsida, Andreaeopsida e Bryopsida: Rome, Antonio Delfino, 817 p.

Pesce, G.L., 2001, The Zinzulusa Cave: An endangered biodiversity "hot spot" of South Italy: Natura Croatica, v. 10, no. 3, p. 207-212.

Prelli, R., and Boudrie, M., 2001, Les Fougères et Plantes Allieées de France et d'Europe Occidentale: Paris, Belin, 429 p.

Russell, M.J., and MacLean, V.L., 2008, Management issues in a Tasmanian tourist cave: Potential microclimatic impacts of cave modifications: Journal of Environmental Management, v. 87, p. 474-483. doi:10.1016/j.jenvman.2007.01.012.

Saiz-Jimenez, C., Cuezva, S., Jurado, V., Fernandez-Cortes, A., Porca, E., Benavente, D., Cañaveras, J.C., and Sanchez-Moral, S, 2011, Palaeolithic art in peril: Policy and science collide at Altamira Cave: Science, v. 334, p. 42-43. doi:10.1126/science. 1206788.

Šebela, S., and Turk, J., 2014, Sustainable use of the Predjama cave (Slovenia) and possible scenarios related to anticipated major increases in tourist numbers: Tourism Management Perspectives, v. 10, p. 37-45. doi:10.1016/j.tmp.2014.01.002.

Sneath, P.H.A., and Sokal, R.R., 1973, Numerical Taxonomy: San Francisco, Freeman, 588 p.

Teramura, A.H., and Sullivan J.H., 1984, Effects of UV-B radiation on photosynthesis and growth of terrestrial plants: Photosynthesis Research, v. 39, no. 3, p. 463-473. doi:10.1007/ BF00014599.

Toomey, R.S. III, Olson, R.A., Kovar, S., Adams, M., and Ward, R.H., 2009, Relighting Mammoth cave's New Entrance: Improving visitor experience, reducing exotic plant growth, and easing maintenance, in White, W.B., ed., Proceedings 15th International Congress of Speleology, Kerrville, Texas: Huntsville, National Speleological Society, vol. 2, p. 1223-1228. 